\title{
A NEW TROGLOBIOTIC SPECIES, ALPIONISCUS (ILLYRIONETHES) IAPODICUS N. SP. (CRUSTACEA: ONISCIDEA: TRICHONISCIDAE), FROM LIKA REGION, CROATIA
}

\author{
Jana BedeK ${ }^{1}$, Mladen Horvatović ${ }^{2}$ \& Ivo M. Karaman ${ }^{2}$
}

${ }^{1}$ Croatian Biospeleological Society, Demetrova 1, HR-10 000 Zagreb, Croatia (jana.bedek@hbsd.hr)

${ }^{2}$ Department of Biology and Ecology, Faculty of Sciences, University of Novi Sad, Trg Dositeja Obradovića 2, SR-21 000 Novi Sad, Serbia (mladen.horvatovic@dbe.uns.ac.rs; ivo.karaman@dbe.uns.ac.rs)

Bedek, J., Horvatović, M. \& Karaman, I. M.: A new troglobiotic species, Alpioniscus (Illyrionethes) iapodicus n. sp. (Crustacea: Oniscidea: Trichoniscidae), from Lika region, Croatia. Nat. Croat., Vol. 26, No. 2, 205-214, 2017, Zagreb.

Alpioniscus (Illyrionethes) iapodicus $\mathrm{n}$. sp. is described and illustrated. Representing the $14^{\text {th }}$ nominal species of the subgenus Illyrionethes from the Dinaric karst, it is a troglobiotic species collected from the caves in the central part of the Lika region, Croatia. The new species belongs to the strasseri group. Morphological characters differentiating A. iapodicus from other strasseri group representatives are discussed.

Key words: Dinaric karst, Lika region, new species, Alpioniscus, Isopoda, terrestrial, Trichoniscidae, troglobiotic

Bedek, J., Horvatović, M. \& Karaman, I. M.: Nova troglobiontska vrsta Alpioniscus (Illyrionethes) iapodicus n. sp. (Crustacea: Oniscidea: Trichoniscidae) iz Like (Hrvatska). Nat. Croat., Vol. 26, No. 2, 205-214, 2017, Zagreb.

U radu se opisuje i ilustrira nova vrsta Alpioniscus (Illyrionethes) iapodicus n. sp. Radi se o troglobiontnoj vrsti prikupljenoj u špiljama središnjeg dijela Like, i predstavlja četrnaestu nominalnu vrstu podroda Illyrionethes iz Dinarskog krša. Nova vrsta pripada grupi strasseri. Raspravlja se o morfološkim obilježjima koji razlikuju A. iapodicus od ostalih predstavnika te grupe. biont

Ključne riječi: Dinarski krš, Lika, nova vrsta, Alpioniscus, Isopoda, kopneni, Trichoniscidae, troglo-

\section{INTRODUCTION}

The genus Alpioniscus includes two subgenera: Alpioniscus Racovitza, 1908, with 14 species, and Illyrionethes Verhoeff, 1927, with 16 species (Schmalfuss, 2003; Taiti \& Argano, 2009; Andreev, 2013a,b). Both subgenera have disjunct ranges, and are distributed across karstic regions in the south of Europe. In all, 13 nominal species of the subgenus Illyrionethes have been recognized in the Dinaric Karst (SCHMALfuss, 2003; BEDEK et al., 2011), while 11 putative species remain undescribed (BEDEK \& TAITI, 2011; Horvatović, 2014). All Illyrionethes species from the Dinaric karst are troglobionts. The new species was collected in 14 localities, underground caves, in the central part of the Lika region, Croatia; 11 of them are known today (Fig. 1). In the type locality, the cave Markov ponor, Lipovo polje, Donji Kosinj, Croatia, it was collected in the most distant channel, referred to as Kanal krivih brojeva (Channel of the wrong numbers) (BAKšı́́, 2008). 


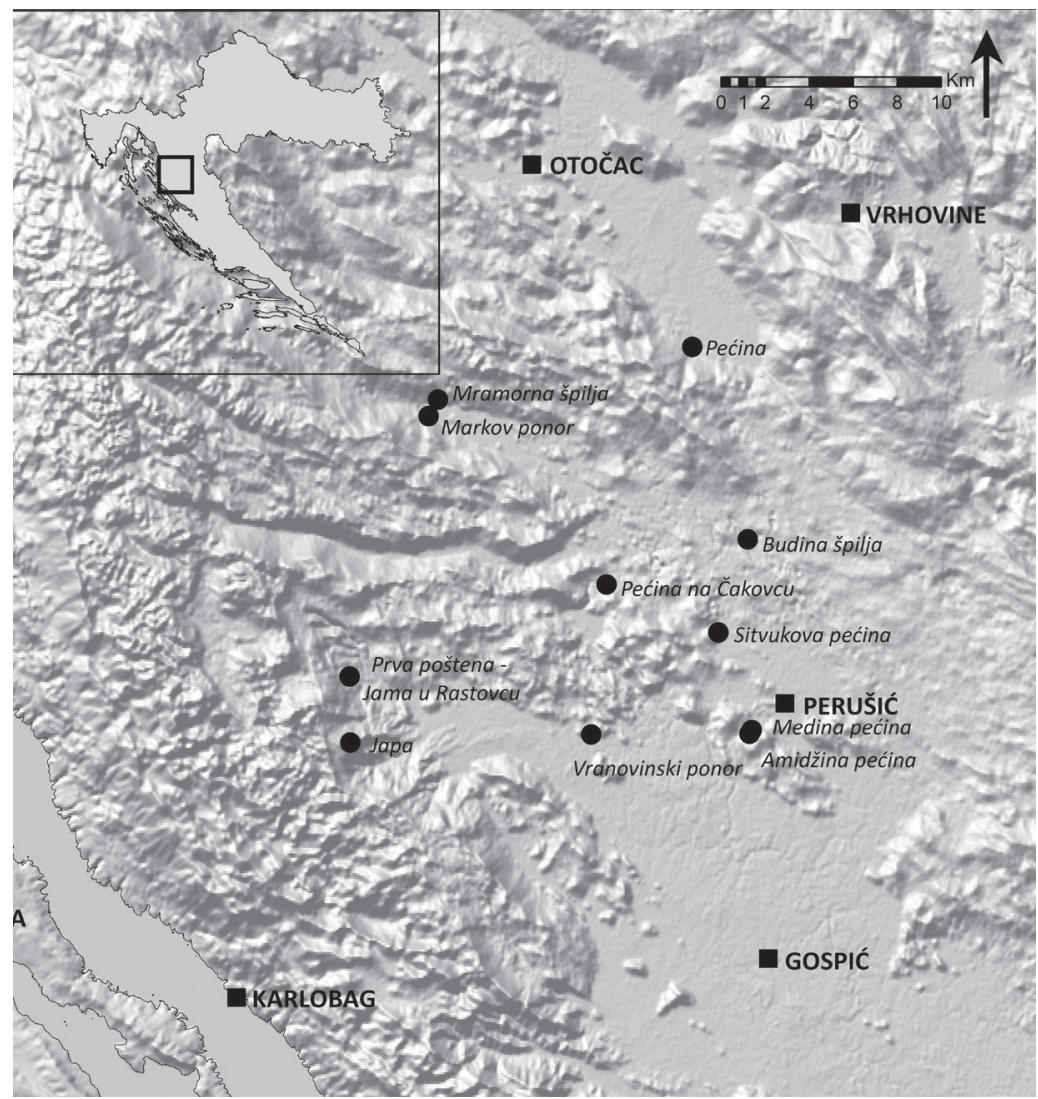

Fig. 1. Distribution of Alpioniscus (Illyrionethes) iapodicus n. sp. (black circles).

\section{MATERIAL AND METHODS}

Specimens were hand collected with tweezers, fixed and stored in $75 \%$ ethanol with glycerol or $96 \%$ ethanol. Several specimens were dissected, and mounted for micropreparations in Hoyer's medium. Identifications are based on morphological characters indicated in the original descriptions. Specimens were examined under a Zeiss Stemi 2000-C and a Zeiss Primo Star microscope (Carl Zeiss, Jena, Germany). The micropreparations were photographed using Canon EOS 40D and EOS Utility software (Canon, Tokyo, Japan). The drawings were made based on the photographs, using CorelDRAW X8 (Corel Corporation, Ottawa, Canada). The examined material, species diagnosis and description, etymology and remarks are given. Terminology used in species description is mainly based on VANDEL (1960, 1962). The locality coordinates are in the WGS84 coordinate system. The map was drawn using ArcMap 10.1 software and related basemap.

Abbreviations:

CBSSC Croatian Biospeleological Society Collection, Zagreb, Croatia

CCC Cave Cadastre of the Republic of Croatia, hosted by Croatian Agency for the Environment and Nature, Zagreb, Croatia (Croatian Agency For the ENvironment AND NATURE, 2017a)

CNHM Croatian Natural History Museum, Crustacea Collection, Zagreb, Croatia

MZUF Museo di Storia Naturale dell'Università di Firenze, Sezione di Zoologia La Specola, Florence, Italy 
SMNS Staatliches Museum für Naturkunde Stuttgart, Isopod Collection, Stuttgart, Germany

ZZDBE Zoological Collection of Department of Biology and Ecology, Faculty of Sciences, University of Novi Sad, Novi Sad, Serbia

\section{TAXONOMY}

Trichoniscidae

Trichoniscinae

Genus Alpioniscus Racovitza, 1908

Subgenus Illyrionethes Verhoeff, 1927

Alpioniscus iapodicus n. sp.

Synonymy: Alpioniscus (Illyrionethes) n. sp. 4: Horvatović, 2014, partim.

Type material. Holotype $\widehat{\jmath}$ Croatia, Lika, Donji Kosinj, Lipovo polje, Markov ponor (CCC No. HR01480), 44,7653017089 ${ }^{\circ} \mathrm{N}, 15,1771778411^{\circ} \mathrm{E}, 19 . X .2011$, leg. J. Bedek (CBSSC IT4109).

Paratypes: $6 \hat{\jmath}, 2$ ㅇ, 2 juv. ibid. (CBSSC IT2479); $4 \hat{\jmath} \jmath, 4 q q$ ibid. (ZZDBE 1142); $2 \hat{\jmath}, 2$ $q$ ibid.

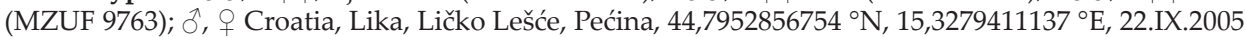
leg. M. Pavlek (CBSSC IT3344); 1 juv. ibid. 7.II.2008 leg. R. Ozimec (CBSSC IT3347); ¿` Croatia, Lika, Donji Kosinj, Lipovo polje, Petranović Draga, Mramorna špilja, 44,772160231 ${ }^{\circ} \mathrm{N}, 15,1823031537{ }^{\circ} \mathrm{E}^{*}$, 30.V.1999 leg. R. Ozimec (CBSSC IT3367); đ̂, 2 우 Croatia, Lika, Perušić, Studenci, Milkovići, Budina špilja (CCC No. HR01195), 44,716915063 ${ }^{\circ} \mathrm{N}, 15,3613735717^{\circ}$ E, 24.VII.2007 leg. M. Pavlek (CBSSC

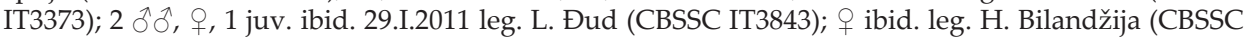
IT3848); 2 juv. ibid. leg. P. Bregović (CBSSC IT3846); 2 ふૈô, q ibid. 11.VI.2011 leg. B. Jalžić (CBSSC IT3374); 3 ふैô, 1 juv. Croatia, Lika, Donji Kosinj, Mlakva, Javorinske drage, Pećina na Čakovcu (CCC

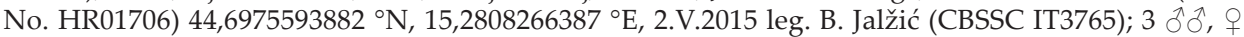
Croatia, Lika, Perušić, Sitvuki, Sitvukova pećina, 44,6786713198 N, 15,3453423752 E, 8.VIII.2014 leg. J. Bedek (CBSSC IT3383); đ̂, o Croatia, Lika, Perušić, Velika Plana, Rastovac, Prva poštena - Jama u Rastovcu (CCC No. HR00953), 44,6582649068 N, 15,1343931909 E, 2.VIII.2015 leg. D. Basara (CBSSC IT3921); + Croatia, Lika, Perušić, Grabovača, Medina pećina, 44,6389475032 ${ }^{\circ} \mathrm{N}, 15,3651981516{ }^{\circ} \mathrm{E}$, 14.VIII.1902, leg. A. Langhoffer (CNHM 653); 2 ડ̄ô, o, 2 juv. ibid. 30.XII.2011, leg. J. Bedek, M. Lukić (CBSSC IT2545); + ibid. 12.V.2014, leg. K. Cindrić (CBSSC IT3381); $q$ ibid. 16.V.2014, leg. J. Bedek (CBSSC IT3907); 1 juv. ibid. 17.V.2014, leg. L. Kekelj (CBSSC IT3382); 3 ổ , 4 oq 9 , 4 juv. Croatia, Lika, Perušić, Grabovača, Amidžina pećina, 44,6373404989 N, 15,3639653667 E, 30.XII.2011, leg. J. Bedek, M. Lukić (CBSSC IT2546); ㅇ ibid. 10.VI.2012 leg. J. Bedek (CBSSC IT3849); ㅇ ibid. leg. L. Deharveng, A. Beddos (CBSSC IT3850); 1 juv. ibid. leg. L. Kekelj (CBSSC IT3378); đ Croatia, Lika, Pazarište, Vranovine, Vranovinski ponor (CCC No. HR00490) $44,6361639727^{\circ} \mathrm{N}, 15,273192897{ }^{\circ} \mathrm{E}, 16 . \mathrm{VII} .1967 \mathrm{leg}$. Deeleman (SMNS 5276); 2 đ̄ô Croatia, Velebit, Pazarište, Japage, špilja Japa (CCC No. HR00344),

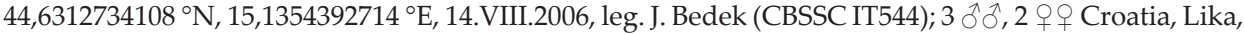
Gospić, Mušaluk, Pećina pri mušalučkom donjem selu (a cave unknown at present), 12.IX.1964 leg. E.

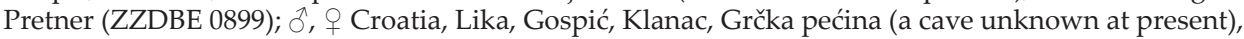
17.VII.1963 leg. Deeleman (SMNS 5344); đ, 7 o $ᄋ$ Croatia, Lika, Pazarište, Mlakva, Mlakvena greda (a cave unknown at present), 9.VII.1965 leg. Deeleman (SMNS 5295).

Other material (for DNA analyses): $2 \hat{\jmath} \hat{\jmath}, 4$ 우, 1 juv. Croatia, Lika, Donji Kosinj, Lipovo polje, Markov ponor (CCC No. HR01480), 44,7653017089 ${ }^{\circ} \mathrm{N}, 15,1771778411^{\circ} \mathrm{E}, 19$. .X.2011, leg. J. Bedek (CBSSC IT4113); ㅈ, 2 q ibid. leg. M. Lukić (CBSSC IT2601); † Croatia, Lika, Ličko Lešće, Pećina, 24.VI.2011 leg. M. Lukić (CBSSC IT3338); đ̊, 3 우, 3 juv. Croatia, Lika, Perušić, Studenci, Milkovići, Budina špilja (CCC No. HR01195), 44,716915063 N, 15,3613735717 E, 11.VI.2011, leg. N. Raguž (CBSSC IT3371); 1

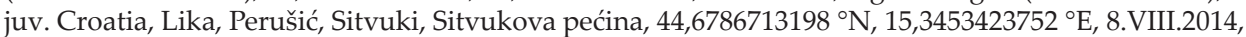
leg. K. Cindrić (CBSSC IT3384); ㅇ Croatia, Lika, Perušić, Grabovača, Medina pećina, 44,6389475032 ${ }^{\circ}$ N, 15,3651981516 ㅌ, 8.VIII.2014, leg. T. Dražina (CBSSC IT3380); + Croatia, Lika, Perušić, Grabovača, Amidžina pećina, 44,6373404989 ${ }^{\circ} \mathrm{N}, 15,3639653667^{\circ} \mathrm{E}, 11 . \mathrm{V} .2014$ leg. K. Cindrić (CBSSC IT3379).

*Coordinates from Croatian Agency for the Environment and Nature (2017b). 
Diagnosis. A medium-sized species characterized by a wide and terminally broadly rounded exopod of male pleopod 1, and outer margin deeply concave at about half of its length; male pereopod 7 merus with a caudal hook-shaped lobe on its proximal part, and pronounced hump on carpus dorsal margin; male pleopod 2 endopod with a short bifid terminal seta; antennal flagellum with up to 10 articles; antennula with up to seven aesthetascs.

Description. Maximum body length: $\widehat{\delta}, 6.9 \mathrm{~mm} ; \uparrow, 8.5 \mathrm{~mm}$. Body (Fig. 2) depigmented, dorsal surface smooth. Cephalon (Fig. 3A) eyes absent, suprantennal line bent downwards, antennal lobes quadrangular with a central depression. Pereon with almost parallel sides, tergites smooth with scattered flask-shaped scale-sensilla (Fig. 3B). Posterior margin of pereonite 1 convex, of pereonites 2 and 3 straight, and of pereonites 4-7 progressively more concave. Pleon narrower than pereon, numerous gland pores laterally on pleonites 4 and 5. Pleonites 3-5 with small posterior points visible in dorsal view (Fig. 3C). Telson median distal part with concave sides and broadly rounded apex and lateral gland pores (Fig. 3C). Antennula (Fig. 3D) of three articles; first article longer than second and third; third article flattened and bearing up to seven aesthetascs on the apical margin. Antenna (Fig. 3E) with fifth article as long as flagellum; flagellum with up to 10 articles, with one row of aesthetascs on the second, third and sometimes fourth, fifth, sixth, seventh and eighth article. Right mandible with one penicil, lacinia mobilis toothed, pars molaris oval in shape with one penicil (Fig. 4A). Left mandible with three penicils, pars molaris oval in shape without penicils (Fig. 4B). Maxillula outer branch with $5+6$ teeth, apically entire, and two slender stems; inner branch with three penicils, outer and middle ones subequal, inner one distinctly longer (Fig. 4C). Maxilla with setose and bilobate apex, inner lobe smaller (Fig. 4D). Maxilliped endite narrow, with a large and segmented apical penicil; palp distally with three rou-

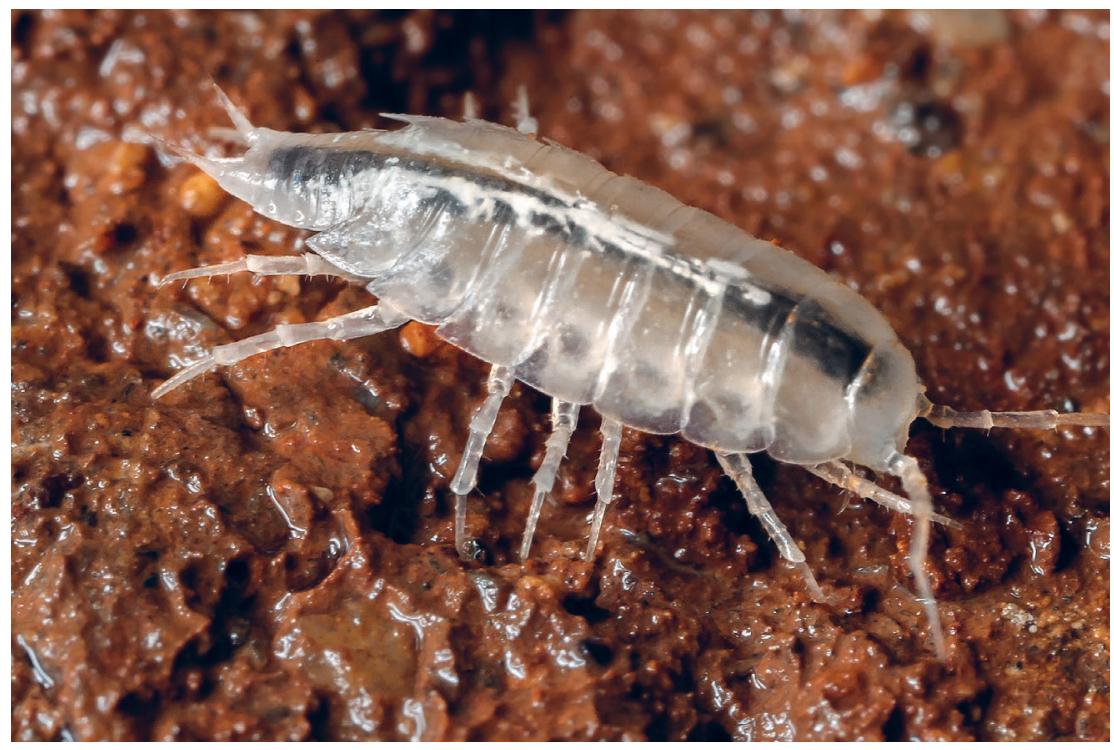

Fig. 2. Alpioniscus (Illyrionethes) iapodicus n. sp. in situ in Croatia, Lika, Perušić, Grabovača, Medina pećina (photo J. Bedek).

nded lobes and one setose setae on outer margin; basal article with two compound small setae; basis with a rounded outer lobe protruding posteriorly and a margin covered with long setae (Fig. 4E). Pereopods with an ungual seta and a large, bifid and setose dactylar seta (Fig. 5A). Uropod (Fig. 3C) with protopod and endopod slightly grooved on outer margin; endopod distinctly shorter than exopod, more proximally inserted. Numerous gland pores on protopod lateral margin.

Male: Pereopod 1-4 (Fig. 5A) similar in shape, with carpus and merus bearing numerous short scales on rostral surface. Pereopod 7 (Fig. 5B-C) ischium with straight sternal margin; merus with concave sternal margin and a setose caudal hook-shaped lobe in the proximal part bearing one seta; carpus dorsal margin with a pronounced hump in it's medial part. Genital papilla (Fig. 6A) simple, with a 


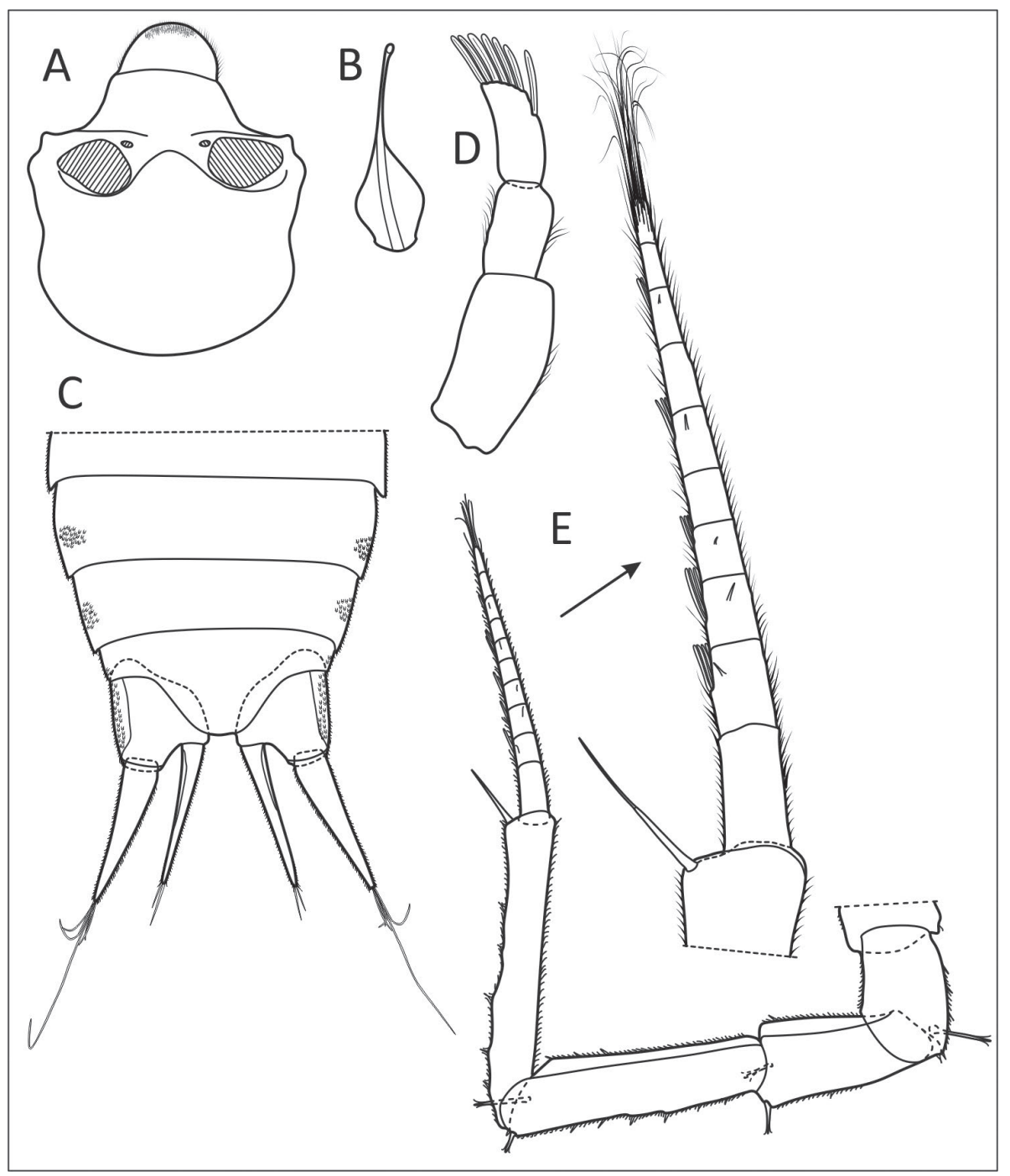

Fig. 3. Alpioniscus (Illyrionethes) iapodicus n. sp. paratype + : A, cephalon; paratype $\delta$ : B, dorsal scale-sensilla; C, pleonites 4, 5, telson and uropods; D, antennula; E, antenna. 


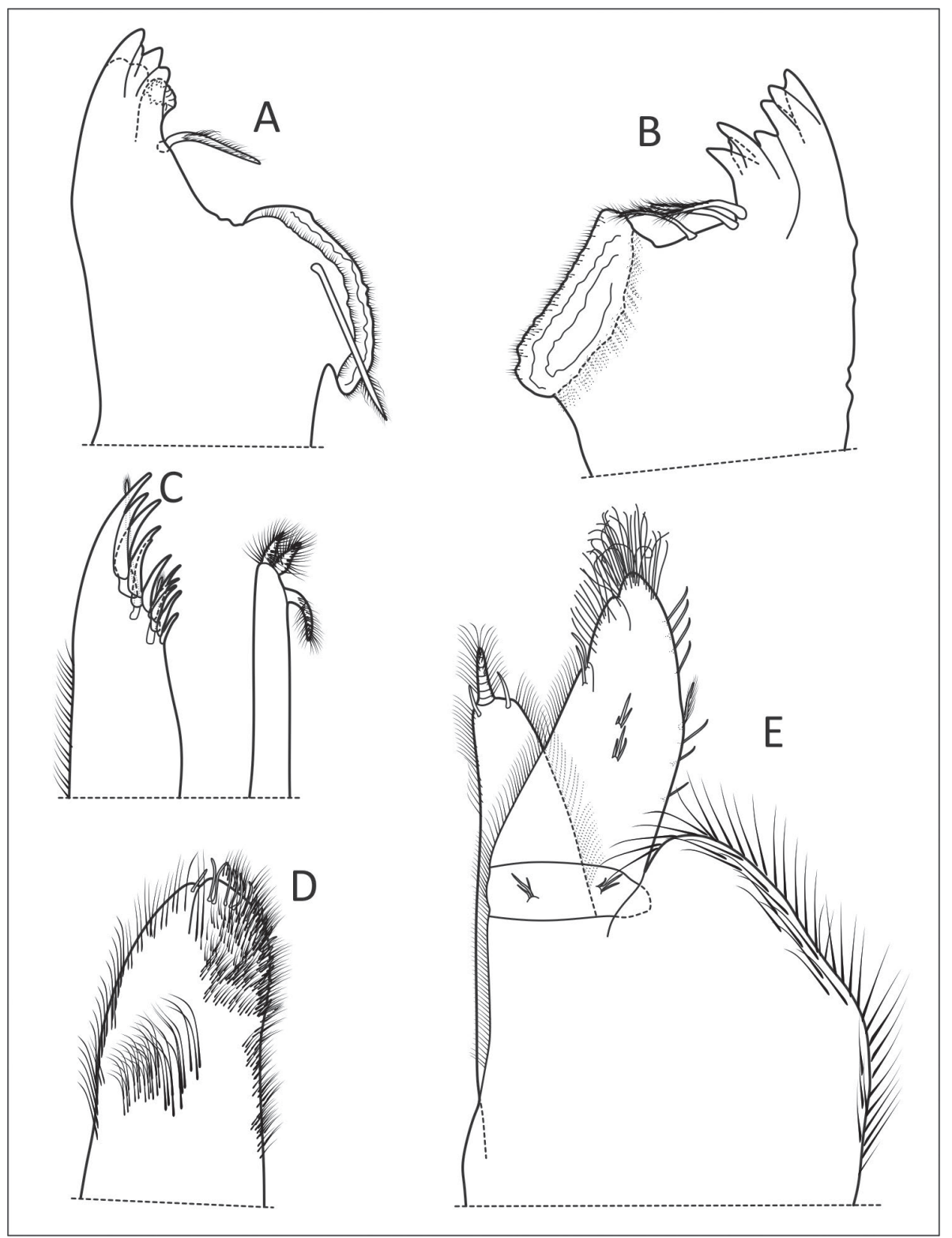

Fig. 4. Alpioniscus (Illyrionethes) iapodicus $\mathrm{n}$. sp. paratype ${ }^{\mathrm{A}}$ : A, right mandible; $\mathrm{B}$, left mandible; $\mathrm{C}$, maxillula; D, maxilla; E, maxilliped. 


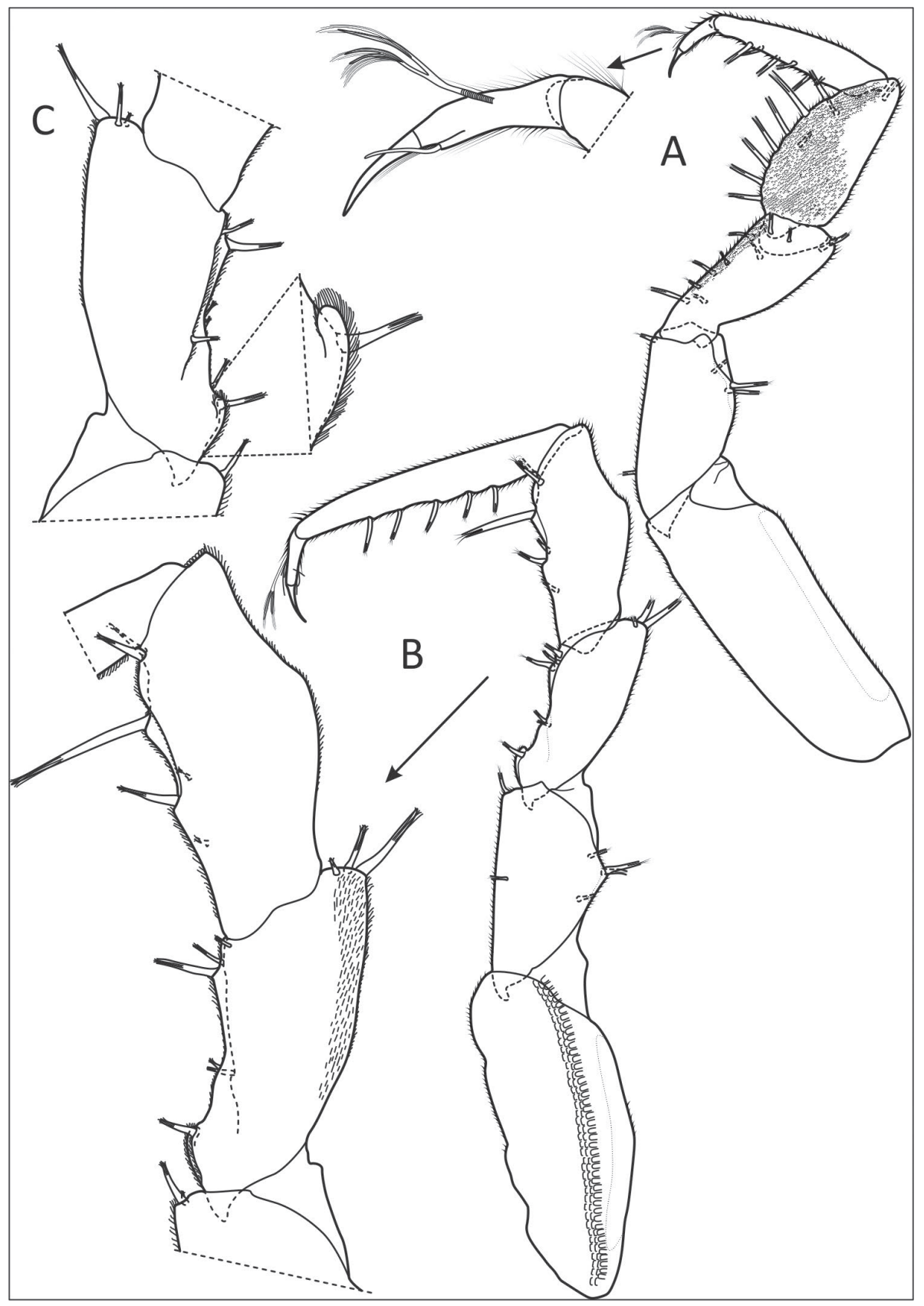

Fig. 5. Alpioniscus (Illyrionethes) iapodicus n. sp. paratype $\widehat{A}$ : A, pereiopod 1; B, pereiopod 7 rostral view with enlargement of merus and carpus; $C$, pereiopod 7 merus caudal view. 


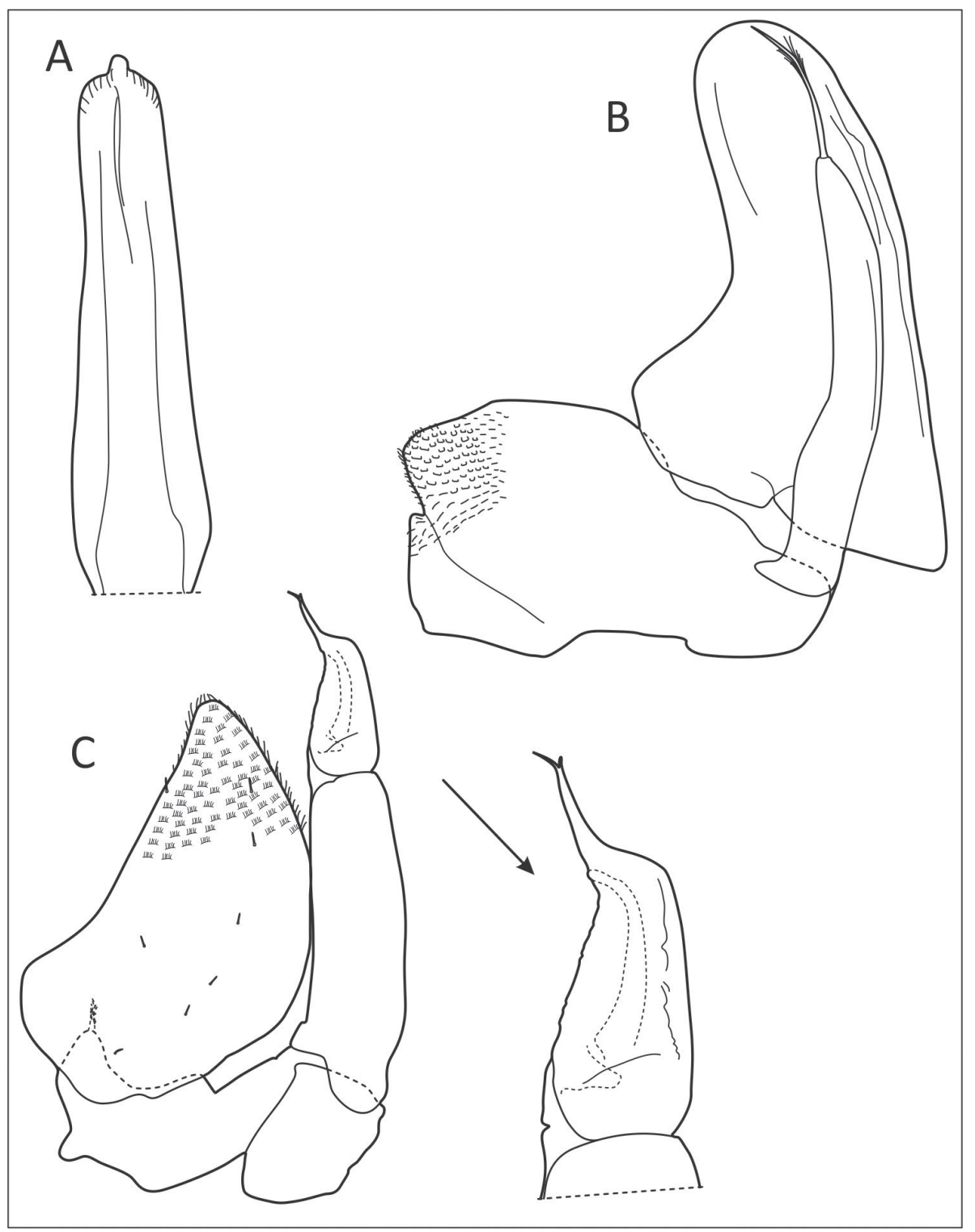

Fig. 6. Alpioniscus (Illyrionethes) iapodicus n. sp. paratype $\widehat{\delta}$ : A, genital papilla; B, pleopod 1; C, pleopod 2 with enlargement of endopod third article. 


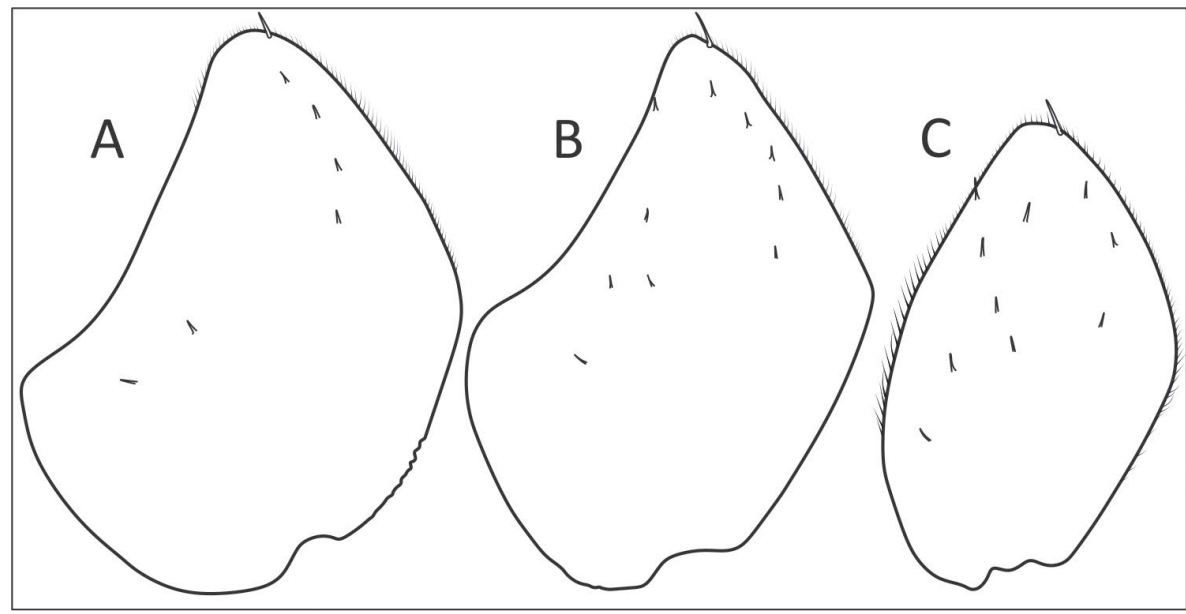

Fig. 7. Alpioniscus (Illyrionethes) iapodicus n. sp. paratype 3 : A, pleopod 3 exopod; B, pleopod 4 exopod; C, pleopod 5 exopod.

rounded apical part. Pleopod 1 (Fig. 6B) exopod wide, terminally broadly rounded, somewhat less than 3 times as long as wide in its medial part, deeply concave outer margin; endopod narrow with almost parallel sides, armed with a long apical seta. Pleopod 2 (Fig. 6C) exopod triangular with convex outer margin; endopod of three articles, slightly longer than exopod, third article about three times shorter than second with a strong bifid terminal point. Pleopod 3-5 exopods as in Fig. 7A-C.

Etymology. The new species is named after the Iapydes (Lat. Iapodes; Hr. Japodi), an ancient tribe inhabiting the montane areas of the Northern Dinaric karst, including the Lika, Kordun and Pounje regions.

\section{Remarks.}

Alpioniscus iapodicus n. sp. belongs to the strasseri group, which comprises A. strasseri (Verhoeff, 1927), A. balthasari (Frankenberger, 1937), A. christiani Potočnik, 1983 and A. absoloni (Strouhal, 1939) (sensu BEDEK \& TAITI, 2011). It shows closest affinities with A. balthasari, widely distributed in Dalmatia, up to the eastern part of Mt Velebit to the northwest and Tomislavgrad in Hercegovina to the east (BEDEK et al., 2011). Upwards to the north it is replaced by A. iapodicus n. sp., clearly differing from the other species of the strasseri-group by the: I) position of the hook-shaped lobe of the male merus 7: on the inner side (A. iapodicus) vs. ventrally positioned (all other strasseri group representatives), II) carpus 7 dorsal hump placed in its medial part (A. iapodicus) vs. proximally positioned (all other strasseri group representatives), and III) pleopod 1 exopod proximally wide (A. iapodicus) vs. narrow (all other strasseri group representatives) (ARCANGELI, 1932; Buturović, 1955; 1957; FrANKENBERGER, 1937; KeSSELyÁk, 1930; Horvatović, 2014; РотоČNiK, 1983; Strouhal, 1938; 1939a; 1939b; VerhoefF, 1927).

\section{ACKNOWLEDGEMENTS}

The authors are grateful to all collectors (see material data) and other (bio)speleologists from the Croatian Biospeleological Society, Biological Students Society BIUS and SO PD Dubovac for helping with the fieldwork; Dr. Helmut Schmalfuss for enabling the review of the Isopoden collection of Staatliches Museum für Naturkunde Stuttgart; Dr. Irena Grbac for enabling the review of the Crustacea collection of the Croatian Natural History Museum, Zagreb, Lida Lamza for improving the English, Dr. Josip Balabanić for reviewing the new Latin name and Dr. Stefano Taiti and Dr. Teo Delić for valuable comments and suggestions. This study was partly supported by the State Institute for Nature Protection, Croatia; the Environmental Protection and Energy Efficiency Fund, Croatia (project leaders Ana Komerički, Branko Jalžić and Helena Bilandžija) and the Ministry of Education, Science and Technological Development of the Republic of Serbia, Grant No. III43007. 


\section{REFERENCES}

Andreev, S., 2013a: A New Cave Species, Alpioniscus gueorguievi n. sp. (Isopoda, Oniscidea, Trichoniscidae) from Continental Greece. Acta zool. bulg., 65(2), 297-298.

Andreev, S., 2013b: A New Cave Species of Genus Alpioniscus (isopoda: Trichoniscidae) from Albania. Acta Zool. Bulg. 65(2), 263-264.

Arcangeli, A., 1932: Isopodi terrestri raccolti dal Dott. Parenzan in una caverna presso Promontore (dintorni di Pola, Istria). Atti dell'Istituto Veneto di Scienze, Lettere ed Arti 91, 1039-1048, pls. 1-9.

BAKšıć, D. 2008: Speleološka istraživanja Markovog ponora 1999. i 2000. godine. Hrvatski speleološki poslužitelj, Available at: http://speleologija.eu/markovponor/ (accessed on 1.11.2017).

Bedek, J., Taiti, S. \& Gottstein, S., 2011: Catalogue and atlas of cave-dwelling terrestrial isopods (Crustacea: Oniscidea) from Croatia. Natura Croatica 20, 237-354.

Bedek, J. \& TAITI, S., 2011: Preliminary taxonomic evaluation and diversity of Alpioniscus (Illyrionethes) taxa in the Dinaric Karst. In: ZIDAR, P. \& ŠTrus, J. (eds.), Proceedings of the $8^{\text {th }}$ International Symposium on the Biology of Terrestrial Isopods. Ljubljana: Biotechnical Faculty, Department of Biology. p. 31-32.

Buturović, A., 1955: Kopneni izopodi iz pećina u oblasti između Rijeka Cetine i Neretve. Godišnjak biološkog instituta u Sarajevu 8, 131-138.

Buturović, A., 1957: O sistematici, biologiji i biogeografiji trihoniscida Jugoslavije. Godišnjak biološkog instituta u Sarajevu 10, 3-67.

Croatian Agency for the Environment and Nature, 2017a: Bioportal - Katastar speleoloških objekata RH. Available at: http://bioportal.hr/. Accessed: 15.XI.2017.

Croatian Agency for the Environment and Nature, 2017b: Nature Protection Information System.

Frankenberger, Z., 1937: Über eine neue Illyrionethes - Art aus Dalmatien. Zoologischer Anzeiger 120, 173-176.

Horvatović, M., 2014: Phyletic relations within Synocheta Legrand, 1946 section (Crustacea, Isopoda, Oniscidea) of the Balkan Peninsula. PhD Thesis [in Serbian with English abstract], University of Novi Sad, pp. 248.

KesselyÁK, A., 1930: Über Isopoden. Zoologischer Anzeiger 91, 50-66.

Ротос̌Niк, F., 1983: Alpioniscus (Illyrionethes) christiani spec. nov., eine neue Trichoniscinae-Art (Isopoda terrestria) aus Jugoslawien. Annalen des naturhistorischen Museums in Wien 84B, 389-395.

Schmalfuss, H., 2003: World catalog of terrestrial isopods (Isopoda: Oniscidea). Stuttgarter Beiträge zur Naturkunde, Serie A 654, pp. 341.

Strouhal, H., 1938: Asseln aus Balkanhöhlen (16. Beitrag zur Isopodenfauna des Balkans.). Zoologischer Anzeiger 124, 269-281.

Strouhal, H., 1939a: Landasseln aus Balkanhöhlen, gesammelt von Prof. Dr. K. Absolon. 4. Mitteilung. Zoologischer Anzeiger 125, 181-190.

Strouhal, H., 1939b: Landasseln aus Balkanhöhlen, in der Sammlung Biospeleologica balcanica, 5. Mitteilung. Mitteilung über Höhlen - und Karstforschung 1939, 114-131.

TAiti, S. \& Argano, R., 2009: New species of terrestrial isopods (Isopoda: Oniscidea) from Sardinia. Zootaxa 2318, 38-55.

VAndel, A., 1960: Faune de France: Isopodes Terrestres (Première Partie). Paris: La Fédération Française des Sociétés de Sciences Naturelles, 64, pp 416.

VAndel, A., 1962: Faune de France: Isopodes Terrestres (Deuxième Partie). Paris: La Fédération Française des Sociétés de Sciences Naturelles, 66, p 417-931.

Verhoeff, K., 1927: Illyrionethes n. g. eine cavernicole Trichonisciden-Gattung. Zoologischer Anzeiger 72 , 268-274. 